\title{
Variability of imposex development and reproductive alterations in the Patagonian gastropod Buccinanops globulosus inhabiting a polluted harbourarea
}

\author{
Mónica Angelina PRIMOST ${ }^{1}$, Andrés AVERBUJ ${ }^{1}$ \& Gregorio BIGATTI ${ }^{1,2}$ \\ ${ }^{1}$ LARBIM (IBIOMAR-CCT CENPAT-CONICET), Bvd. Brown 2915, U9120ACV Puerto Madryn, Chubut, \\ Argentina. ${ }^{2}$ Facultad de Ciencias Naturales, Universidad Nacional de la Patagonia San Juan Bosco (UNPSJB), \\ Bvd. Brown 3051, U9120ACV Puerto Madryn, Chubut, Argentina. \\ E-mail: averbuj@cenpat-conicet.gob.ar
}

\begin{abstract}
The aim of this work was to study the reproductive output and imposex parameters of the caenogastropod Buccinanops globulosus inhabiting a harbour area, with high maritime traffic and pollution. The results showed higher imposex incidence for non-gravid females than for gravid females (carrying egg capsules). Among imposex-affected females, mean penis size was significantly larger in non-gravid $(3.4 \mathrm{~mm})$ than gravid $(1.5 \mathrm{~mm})$ females. In B. globulosus usually a single juvenile hatches per egg capsule, but in this study capsules with multiple embryos were found. Overall, these results suggest a relationship between imposex development and alterations on the reproductive output of $B$. globulosus females living in adverse environmental conditions (polluted area).
\end{abstract}

Key words: Maritime traffic, Offspring, Pollution, Reproduction, TBT.

Resumen: El objetivo de este trabajo fue estudiar parámetros reproductivos y desarrollo de imposex en el caenogasterópodo Buccinanops globulosus que habita en una zona portuaria de alto tráfico marítimo y con presencia de contaminantes. Los resultados mostraron una mayor incidencia de imposex en hembras sin ovicápsulas que en hembras con ovicápsulas. Entre las hembras con imposex, el desarrollo del pene fue significativamente mayor en aquellas sin ovicápsulas (3.4 $\mathrm{mm}$ ) que en las hembras con ovicápsulas (1,5 mm). En B. globulosus comúnmente un solo juvenil eclosiona por cada cápsula, sin embargo, en este estudio se registraron capsulas con múltiples embriones. Todos estos resultados sugieren una relación entre el desarrollo de imposex y alteraciones en los parámetros reproductivos de las hembras de $B$. globulosus que habitan en sitios con condiciones ambientales adversas (área contaminada).

Palabras clave: Tráfico marítimo, Descendencia, Contaminación, Reproducción, TBT.

\section{INTRODUCTION}

Harbour activities, in particular maritime traffic, imply the release of toxic substances such as tributyltin (TBT) (Fent, 2003). This toxic compound can be accumulated, persisting in the sediments for up to 2.5 years (de Mora et $a l .$, 1995). In female caenogastropods, the neoformation of a penis or vas deferens in individuals exposed to TBT is known as imposex (Gibbs \& Bryan, 1996). Because imposex is irreversible (Stroben et al., 1992) researchers worldwide have used this phenomenon as a marine pollution biomarker associated to maritime traffic (Axiak et al., 2003, Ketata et al., 2008). In areas highly polluted with TBT, sterile females and popula- tion declines have been observed (Oehlmann et $a l$. , 2007). In Argentinean harbour areas, several gastropod species have been reported to be affected by imposex, including Buccinanops globulosus, and its congeners B. monilifer and B. cochlidium (Penchaszadeh et al., 2001, Bigatti et al., 2009, Averbuj \& Penchaszadeh, 2010a). Pollutants such as TBT, heavy metals and polyaromatic hydrocarbons (PAHS) were detected in Nuevo Gulf at north Patagonia, Argentina (Gil et al., 2006, Massara Paletto et al., 2008, Bigatti et al., 2009). The highest concentrations of TBT were reported in the harbour area of Nuevo gulf, with up to $174.81 \mathrm{ng}(\mathrm{Sn}) \mathrm{g}^{-1}$ in sediments and $345.27 \mathrm{ng}(\mathrm{Sn}) \mathrm{g}^{-1}$ in body tissues of the gastropod Odontocymbiola magellanica (del Brío, 2011). 
Buccinanops globulosus presented high values of imposex parameters in moderately polluted areas with TBT concentrations of $0.4 \mathrm{ng}(\mathrm{Sn}) \cdot \mathrm{g}^{-1}$ dry sediment; thus, it was classified as a good indicator due to its high sensitivity to low concentrations of TBT (Bigatti et al., 2009).

Buccinanops globulosus lives mostly buried in sandy or muddy bottoms (Scarabino, 1977). This species is edible and is part of an expanding artisanal fishery (Narvarte, 2006, Averbuj et al., 2014). Adult females spawn once a year a variable number of egg capsules that are attached to their own shells (Penchaszadeh, 1971). Generally one $B$. globulosus crawling juvenile, measuring between 3-7 $\mathrm{mm}$, hatches from each egg capsule (Penchaszadeh, 1971, Narvarte, 2006, Averbuj et al., 2014).

The aim of this work was to study the reproductive output and imposex parameters of $B$. globulosus inhabiting a polluted area.

\section{MATERIALS AND METHODS}

Females of B. globulosus were collected during February 2012 when egg capsules with embryos in late stages of development are most abundant (Averbuj et al., 2014).The "gravid females" occur mainly from October to March, when the water temperature ranges between $11^{\circ} \mathrm{C}$ and $18^{\circ} \mathrm{C}$ (Averbuj et al., 2014). This work was performed at Luis Piedra Buena Harbour (LPBH, $42^{\circ} 45^{\prime} 45^{\prime}$ " $\mathrm{S}$ and $64^{\circ} 1^{\prime} 51^{\prime \prime} \mathrm{W}$ ), a high maritime traffic area with $\sim 730$ vessels per year (APPM, 2013). In this area sporadic catches of $B$. globulosus are carried out for human consumption.

Buccinanops globulosus individuals were captured by SCUBA diving, then placed in glass aquaria and sexed by presence (female) or absence (male) of the accessory glands. The gastropods were counted and classified into three categories: female, male and gravid female (carrying egg capsules). This species was chosen considering its sensitivity to TBT and the fact that the egg capsules are attached to the female's own shell (Penchaszadeh, 1971, Averbuj \& Penchaszadeh, 2010b), allowing for a straightforward estimation of reproductive output of each gravid female. Total shell length (TSL), female penis length (FPL) and male penis length (MPL) were measured. The imposex percentage (I\%), was estimated and the relative penis length index (RPLI) was calculated according to (Gibbs \& Bryan, 1994). Reproductive output was estimated for gravid females (Fig. 1) when embryos were at hatching stage (Averbuj et al., 2014). The fol-
Table 1: Imposex and reproductive output parameters (mean $\pm \mathrm{SD}$, where corresponds) in B. globulosus. Abbreviations:FPL $=$ female penis length, $\mathrm{MPL}=$ male penis length, $\mathrm{RPLI}=$ relative penis length index.

\begin{tabular}{l|c|c|c|c}
\hline & Imposex \% & FPL $(\mathrm{mm})$ & RPLI & MPL (mm) \\
\hline Without EC & 100 & $3.40 \pm 0.95$ & 25.03 & \\
With EC & 89 & $1.50 \pm 1.05$ & 11.06 & $13.25 \pm 5.6$ \\
\hline
\end{tabular}

lowing parameters were considered for reproductive output: a) number of egg capsules per female (\# EC), b) number of embryos per egg capsule, c) total number of embryos per female and d) mean embryo size per female. Egg capsules with lysed eggs/embryos or undeveloped embryos were not considered but special attention was taken for cases of embryo malformation. To estimate the mean embryo size (d), 10 hatchling embryos were randomly removed from each of 15 gravid females and measured to determine embryo shell length (ESL) under a stereomicroscope. The Mann-Whitney test was used to test for differences in the mean female shell length and mean female penis length (FPL), between gravid and non-gravid imposex females. In all cases the STATISTICA $7^{\circledR}$ software was used.

\section{RESULTS}

A total of 67 individuals of Buccinanops globulosus were studied. The minimum TSL of gravid females was $37.78 \mathrm{~mm}$ and the total shell length (TSL) was not significantly different $(\mathrm{U}=243.5$; $\mathrm{p}=0.713 ; \mathrm{n}=43)$ between gravid $(41.88 \pm 2.40$ $\mathrm{mm})$ and non-gravid $(41.58 \pm 2.56 \mathrm{~mm})$ females. Imposex parameters (I\%, FPL and RPLI) were higher in females without egg capsules than in gravid females (Table 1). Furthermore, all females without imposex incidence were gravid. Penis length was significantly larger in non-gravid than gravid females $(\mathrm{U}=44.0, \mathrm{p}<0.0001, \mathrm{n}=41$ ) (Table 1). None of the studied females were sterilized or exhibited an occluded gonopore.

On average $47.89 \pm 2.7$ egg capsules occurred per female, with $56.73 \pm 4.3$ total embryos per females and $1.19 \pm 0.07$ embryos per egg capsule. A high proportion (74\%) of gravid females carrying egg capsules with multiple embryos (ME: $>1$ embryo/capsule) was recorded. On average, $17.3 \%$ of the egg capsules contained multiple embryos. The mean embryo shell length (ESL) was 

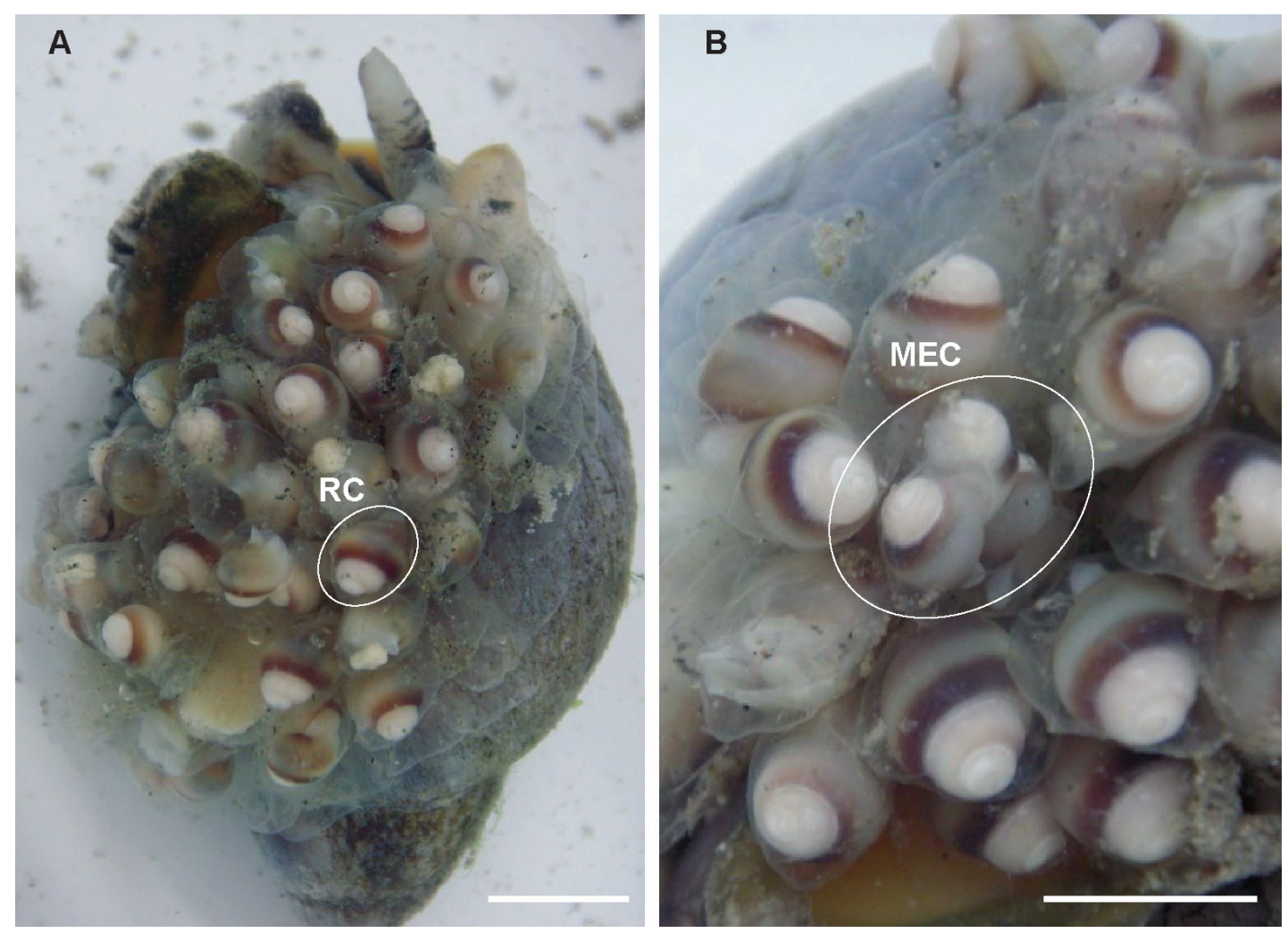

Fig. 1. Gravid females of B. globulosus with conspicuous egg capsules in late stages of development. (A) General aspect of the capsule mass, regular capsules with 1 embryo; (B).Capsules with multiple embryos. Abbreviations: MEC, multiple embryos capsule, RC, regular capsule. Scale bars $=10 \mathrm{~mm}$.

$5.04 \pm 0.06 \mathrm{~mm}$. No malformed embryos were observed during this study.

\section{DISCUSSION}

The reproductive output, defined as the mean number of embryos (and their sizes) spawned per female, has been shown to be susceptible to variability in different environmental conditions (Ramirez Llodra, 2002). The effects of pollutants on gastropod reproductive output has been associated with histological changes in gonads and aborted egg capsules in females (Gibbs et al., 1991, Axiak et al., 2003, Oetken et al., 2004). Although generally in $B$. globulosus only one embryo is developed per egg capsule (Penchaszadeh, 1971), a population recently studied in Golfo Nuevo showed $0.22 \%$ of egg capsules with multiples embryos (Averbuj et al., 2014). Our results showed that gravid females presented on average a large proportion of egg capsules with multiple embryos (17.3\%). Differences in imposex parameters between gravid and non-gravid females are remarkable. Imposex-affected gravid females showed significantly smaller penis than nongravid ones, suggesting that the later may be more severely affected by imposex, since exposition to the endocrine disrupter tributyltin (TBT) induces a concentration -and time- dependent imposex development in gastropod females (Bettin et al., 1996). Similarly, in B. monilifer from Mar del Plata (northern Argentina), females that succeed in spawning showed significantly lower imposex incidence (imposex \% and penis length) than the rest of the female population (Averbuj \& Penchaszadeh, 2010a). It is important to note that the larger penis recorded in non-gravid females were not related to female sterilization by gonopore occlusion, although it clearly evidence major imposex affection. This suggests either major exposure or individual sensibility to TBT (and probably other pollutants that might affect reproductive output) in $B$. globulosus.

Higher penis development infemales with reduced reproductive capacity may be suggesting an alteration of TBT on the reproductive physi- 
ology, in particular affecting gonadic proceses (Ramirez Llodra, 2002, Oehlmann \& SchulteOehlmann, 2003). The studied population of $B$. globulosus could be negatively affected, limiting the number of females capable of reproduction and, complementarily altering its reproductive output under unfavorable environmental conditions as reported for other gastropods species (Marshall et al., 2008, Chatzinikolaou \& Richardson, 2010, Collin \& Spangler, 2012). This pattern, evident in the genus Buccinanops due to its particular breeding behavior, may be occurring in other gastropod species inhabiting similar polluted environments.

\section{ACKNOWLEDGEMENTS}

Authors would like to thank Soledad Zabala and Juan Pablo Livore for helpful comments that greatly improved the final version of the manuscript. This work was partially supported by PICT 1232, PICT 2929, SA1101, PIP 067 and PICT 1491. PADI Foundation supported MP.

\section{BIBLIOGRAPHY}

APPM. 2013. Administración Portuaria de Puerto Madryn. http://www.appm.com.ar/.

Averbuj, A. \& P.E. Penchaszadeh. 2010a. On the reproductive biology and impact of imposex in a population of Buccinanops monilifer from Mar del Plata, Argentina. Journal of the Marine Biological Association of the United Kingdom 90(4): 729-734.

Averbuj, A. \& P.E. Penchaszadeh. 2010b. Reproductive seasonality, oviposition and development of the nassariid whelk Buccinanops cochlidium (Dillwyn, 1817) in Patagonia, Argentina. Journal of Molluscan Studies 76: 25-32.

Averbuj, A., M.N. Rocha \& S. Zabala. 2014. Embryonic development and reproductive seasonality of Buccinanops globulosus (Nassariidae) (Kiener, 1834) in Patagonia, Argentina. Invertebrate Reproduction and Development 58(2): 138-147.

Axiak, V., D. Micallef, J. Muscat, A. Vella \& B. Mintoff. 2003. Imposex as a biomonitoring tool for marine pollution by Tributyltin: some further observations. Environment International 28(8): 743-749.

Bettin, C., J. Oehlmann \& E. Stroben. 1996. TBTinduced imposex in marine neogastropods is mediated by an increasing androgen level. Helgoland Marine Research 50: 299-317.

Bigatti, G., M.A. Primost, M. Cledón, A. Averbuj, N. Theobald, W. Gerwinski, W. Arntz, E. Morriconi \& P.E. Penchaszadeh. 2009. Biomonitoring of TBT contamination and imposex incidence along 4700 $\mathrm{km}$ of Argentinean shoreline (SW Atlantic: From $38 \mathrm{~S}$ to 54S). Marine Pollution Bulletin 58: 695701.

Collin, R. \& A. Spangler. 2012. Impacts of adelphophag- ic development on variation in offspring size, duration of development, and temperature-mediated plasticity. Biological Bulletin 223(3): 268-277.

Chatzinikolaou, E. \& C.A. Richardson. 2010. Parental size and environmental conditions affect egg capsule production by Nassarius reticulatus (Linnaeus 1758) (Gastropoda: Nassariidae). Journal of Experimental Marine Biology and Ecology 390: 1421.

de Mora, S.J., C. Stewart \& D. Phillips. 1995. Sources and rates of degradation of Tri(n-butyl)tin in marine sediments near Auckland, New Zealand. Marine Pollution Bulletin 30: 50-57.

del Brío, F. 2011. Determinacion de TBT, factores de acumulación e imposex, en el volutido Odontocymbiola magellanica en la Bahia Nueva, Chubut. Degree Thesis, Universidad Nacional de la Patagonia San Juan Bosco, Argentina.

Fent, K. 2003. Ecotoxicological problems associated with contaminated sites. Toxicology Letters 140/141: 353-365.

Gibbs, P.E. \& G.W. Bryan. 1994. Biomonitoring of Tributyltin (TBT) pollution using the imposex response of neogastropod molluscs. In: J.M. Kramer Kees (ed), Biomonitoring of Coastal Waters and Estauries, pp. 205-226. Boca Raton.

Gibbs, P.E. \& G.W. Bryan. 1996. Reproductive failure in the gastropod Nucella lapillus associated with Imposex caused by Tributyltin pollution: A review. In: M.A. Champ \& Seligman P.F. (eds), Organotin, pp. 259-280. Netherlands: Springer.

Gibbs, P.E., P.L. Pascoe \& G.W. Bryan. 1991. Tributyltininduced imposex in Stenoglossan gastropods: Pathological effects on the female reproductive system. Comparative Biochemistry and Physiology, Part C: Comparative Pharmacology 100(1/2): 231235.

Gil, M.N., A. Torres, M. Harvey \& J.L. Esteves. 2006. Metales pesados en organismos marinos de la zona costera de la Patagonia argentina continental. Revista de Biologia Marina y Oceanografia 41(2): 167-176.

Ketata, I., X. Denier, A. Hamza-Chaffai \& C. Minier. 2008. Endocrine-related reproductive effects in molluscs. Comparative Biochemistry and Physiology, Part C: Comparative Pharmacology 147: 261-270.

Marshall, D.J., R. Bonduriansky \& L.F. Bussière. 2008. Offspring size variation within broods as a bethedging strategy in unpredictable environments. Ecology 89(9): 2506-2517.

Massara Paletto, V., M.G. Commendatore \& J.L. Esteves. 2008. Hydrocarbon levels in sediments and bivalve mollusks from Bahía Nueva (Patagonia, Argentina): An assessment of probable origin and bioaccumulation factors. Marine Pollution Bulletin 56: 2082-2105.

Narvarte, M.A. 2006. Biology and fishery of the whelk Buccinanops globulosum (Kiener, 1834) in northern coastal waters of the San Matías Gulf (Patagonia, Argentina). Fisheries Research 77: 131-137.

Oehlmann, J., P.D. Benedetto, M. Tillmann, M. Duft, M. Oetken \& U. Schulte-Oehlmann. 2007. Endocrine 
disruption in prosobranch molluscs: evidence and ecological relevance. Ecotoxicology 16: 29-43.

Oehlmann, J. \& U. Schulte-Oehlmann. 2003. Topic 4.2. Endocrine disruption in invertebrates. Pure and Applied Chemistry 75(11-12): 2207-2218.

Oetken, M., J. Bachmann, U. Schulte-Oehlmann \& J. Oehlmann. 2004. Evidence for endocrine disruption in invertebrates. International Review of Cytology 236: 1-44.

Penchaszadeh, P.E. 1971. Aspectos de la embriogenesis de algunos gasterópodos del genero Buccinanops d'Orbigny, 1841 (Gastropoda, Prosobranchiata, Buccinidae). Physis 30(81): 475-482.

Penchaszadeh, P.E., A. Averbuj \& M. Cledón. 2001. Imposex in gastropods from Argentina (South-
Western Atlantic). Marine Pollution Bulletin 42(9): 790-791.

Ramirez Llodra, E. 2002. Fecundity and life-history strategies in marine invertebrates. Advances in Marine Biology 43: 87-170.

Scarabino, V. 1977. Moluscos del Golfo San Matías, provincia de Río Negro, República Argentina. Inventario y claves para su identificación. Comisión de la Sociedad Malacológica de Uruguay 4: 177285.

Stroben, E., J. Oehlmann \& P. Fioroni. 1992. The morphological expression of imposex in Hinia reticulata (Gastropoda: Buccinidae): a potential indicator of tributultin. Marine Biology 13(4): 625-636.

Recibido: 7-V-2015

Aceptado: 30-IX-2015 